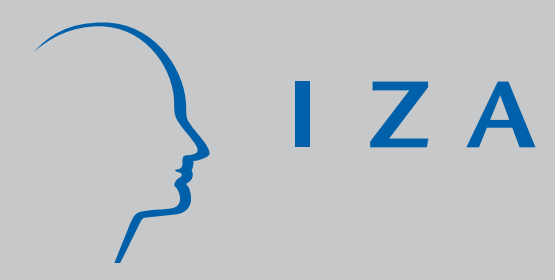

IZADP No. 3969

Switching Costs and Occupational

Transition into Self-Employment

Andrew Henley

J anuary 2009 


\title{
Switching Costs and Occupational Transition into Self-Employment
}

\author{
Andrew Henley \\ Swansea University \\ and IZA
}

Discussion Paper No. 3969

January 2009

\author{
IZA \\ P.O. Box 7240 \\ 53072 Bonn \\ Germany \\ Phone: +49-228-3894-0 \\ Fax: +49-228-3894-180 \\ E-mail: iza@iza.org
}

\begin{abstract}
Any opinions expressed here are those of the author(s) and not those of IZA. Research published in this series may include views on policy, but the institute itself takes no institutional policy positions.

The Institute for the Study of Labor (IZA) in Bonn is a local and virtual international research center and a place of communication between science, politics and business. IZA is an independent nonprofit organization supported by Deutsche Post Foundation. The center is associated with the University of Bonn and offers a stimulating research environment through its international network, workshops and conferences, data service, project support, research visits and doctoral program. IZA engages in (i) original and internationally competitive research in all fields of labor economics, (ii) development of policy concepts, and (iii) dissemination of research results and concepts to the interested public.
\end{abstract}

IZA Discussion Papers often represent preliminary work and are circulated to encourage discussion. Citation of such a paper should account for its provisional character. A revised version may be available directly from the author. 
IZA Discussion Paper No. 3969

January 2009

\section{ABSTRACT \\ Switching Costs and Occupational Transition into Self-Employment}

Contemporary dynamic theories of self-employment choice focus on occupational switching costs, and the risk associated with entrepreneurial income streams. However little or no previous research has addressed the question of what factors determine the length of time that it takes aspiring entrepreneurs to switch into self-employment. The existence of switching costs suggests that choice may be subject to 'hysteresis' (akin to investment under conditions of irreversibility and uncertainty). This paper presents empirical evidence on the dynamics of entrepreneurial transition drawing on data from Waves 8 to 16 of the British Household Panel Survey. The paper estimates a discrete-time duration model of the time between initial expressions of aspiration to transition into self-employment. The model incorporates measures of local economic volatility to capture uncertainty, as well as a range of demographic and background factors which may be associated with lower switching costs. Econometric results reveal that switching costs are lower for men, older individuals and graduates, as well as for those with prior entrepreneurial experience. Increased volatility in the local housing market is also found to be associated with slower transition, suggesting that information about the housing market may form an important indicator of uncertainty for aspiring entrepreneurs.

JEL Classification: J23, J24, C23

Keywords: self-employment, entrepreneurship, switching costs, occupational choice

Corresponding author:

Andrew Henley

School of Business and Economics

Swansea University

Singleton Park

Swansea, SA2 8PP

United Kingdom

E-mail: a.g.henley@swansea.ac.uk 


\section{Introduction}

Contemporary economic theories of entrepreneurship are rooted in the notion that entrepreneurship should be seen as an occupational choice. ${ }^{1}$ Utility maximising individuals choose entrepreneurship over paid (organisational) employment on the basis of relative attractiveness. This assessment may be on the basis of financial reward but may also take into account other relative non-pecuniary benefits. Dynamic models introduce two important additional elements. The first is that occupational switching may be costly, and therefore that transitions between paid employment and entrepreneurship may not be instantaneous once an individual has made a positive decision to launch a business venture. The costs of switching into entrepreneurship may include financial start-up costs, costs associated with business preparation and acquisition of business skills, and costs in terms of sacrificed experienced from giving up paid employment. Once committed these costs may be irrecoverable. The second is that entrepreneurship is risky. A combination of switching costs and uncertainty about future returns leads to models in which commitment to invest in a business venture may be subject to delay (Dixit and Pindyck, 1994; Dixit and Rob, 1994). Aspiring entrepreneurs, facing significant switching costs and uncertainty may delay occupational choice decisions until the value of the "exercising" the option to launch a new venture exceeds the return from the alternative choice by some critical threshold value. Thus occupational choice decisions may be subject to a zone of "inertia" in which aspiring entrepreneurs will remain aspiring rather committing to a change of occupation - termed "hysteresis" in occupational choice by Dixit and Rob (1994). The higher the switching costs the greater the level of hysteresis. 
This paper presents empirical evidence on the dynamics of entrepreneurial transition drawing on data from Waves 8 to 16 of the British Household Panel Survey and estimates a discrete-time duration model of the time between initial expressions of aspiration to transition into self-employment. The purpose of this is to address empirically the question of occupational switching costs, by focusing on the extent to which the length of time that it takes for an aspiring entrepreneur to transition into self-employment is associated with a range of influences, including indicators of the volatility of local economic circumstances.

The remainder of the paper is structured as follows. Section 2 provides a background discussion and reviews the relevant literature. Section 3 describes the empirical methodology adopted. Section 4 explains the BHPS data source and discusses the choice of model covariates. Section 5 details the econometric results and section 6 provides conclusions.

\section{Background}

The dynamics of transition into self-employment or entrepreneurship have been the subject of extensive recent research. This research is motivated be a desire to understand the processes through which individual entrepreneurs formulate and establish new business ventures. A substantial literature has addressed the issue of entrepreneurship as an occupational choice over other options, most notably organisational employment. The recent availability of longitudinal survey data, either designed specifically to address entrepreneurial dynamics or taken from general purpose individual and household surveys, has allowed researchers to address questions related to entrepreneurial transition behaviour. Such work identifies samples of nascent or aspiring entrepreneurs and tracks these individuals as they may or may not eventually succeed in establishing a new business venture. Recent research 
has shown that in proportionate terms the numbers of individuals with clearly formed aspirations towards entrepreneurship who succeed in a new venture creation is small (Henley 2007). Many new venture start-ups appear to be conceived and executed hastily, raising concerns about the level of preparedness of many would-be entrepreneurs. Yet little or no research has been conducted on the question of exactly how long it takes for an expression of entrepreneurial aspiration to translate into an actual new venture (or transition into selfemployment), and on what factors may be associated with that length of time. Thus there is a need to investigate how delay in occupational choice varies across heterogeneous samples of aspiring or nascent entrepreneurs.

Extensive empirical research has addressed the factors associated with individual's aspirations to become an entrepreneur and with self-employment occupational choice. The literature on entrepreneurial aspiration draws on themes from economics, psychology and sociology, addressing a range of both cognitive and non-cognitive factors. ${ }^{2}$ Aspiring entrepreneurs may differ from non-entrepreneurs in terms of personal characteristics, family and social background and personal resources (Carroll and Mosakowski, 1987; Bates, 1995; Kolvereid, 1996a and 1996b, Delmar and Davidsson, 2000). Some empirical analyses begin by defining and identifying nascent entrepreneurs in the general population and then track these as they achieve success in establishing a new venture. The most notable such study is the US Panel Study of Entrepreneurial Dynamics (PSED) (see Gartner et al., 2004). This work has deepened understanding of the process of new venture formation and the characteristics of successful aspiring entrepreneurs. Other research has tracked transition into entrepreneurship, or more precisely self-employment, using nationally representative general longitudinal surveys. Most is concerned with transition into self-employment, and ignores prior aspiration. Katz (1990), using the US Panel Study on Income Dynamics (PSID), and 
Henley (2007), using the British Household Panel Survey, document the level of entrepreneurial aspiration and examine rates of transition from aspiration to self-employment.

A very substantial literature has focused on self-employment choice, and here economic factors have been the subject of a greater level of analysis. Le (1999) and Parker (2004) provide thorough and extensive surveys of the literature. Blanchflower (2000) documents international variation. A number of key themes emerge. There is typically a strong relationship between age and self-employment. Although younger workers may indicate interest in self-employment, it is prime age individuals who are more likely to be in self-employment. So experience may be important. Educational attainment is found to be less of an influence. Self-employment is more prevalent amongst men then women, and particularly amongst married men. The presence of a spouse may offer insurance against risky self-employment income. A number of studies have investigated the impact of minority ethnic status (for example, Fairlie and Meyer, 1996; Clark and Drinkwater, 2000; Hammerstadt, 2004). Typically minorities are more likely to choose self-employment, but there may be a range of reasons for this, covering both "push" and "pull” influences. Discrimination in the salaried labour market will make self-employment relatively more attractive; self-employment may provide an easier occupational choice for minorities who may have limited local language skills or overseas educational qualifications and experience which are not recognised.

Entrepreneurship or self-employment may offer the opportunity for greater employment flexibility and so may be attractive to those for whom full-time employment is problematic. Although research on this theme is sparse, it leads to two typical empirical findings - firstly that those will ill-health or who have experienced prior spells of economic 
inactivity may be more likely to choose self-employment; secondly those who report higher levels of dissatisfaction in prior periods of paid employment may be more likely to choose self-employment (see Parker, 2004 for further discussion and Zissimopoulos and Karoly, 2007 for recent evidence).

A further theme which has attracted empirical support is that self-employment choice may be influenced by background, either as previous experience of entrepreneurship (Rotefoss and Kolveried 2005) or through having parental experience of entrepreneurship (de Wit and van Winden, 1989; Dunn and Holtz-Eakin, 2000). Parental background and prior experience may provide an important resource which enables the potential entrepreneur to reach a more positive judgement about the extent to which any prospective business venture may succeed. The issue of the resourcing of a new venture is also addressed in work on the relationship between self-employment and financial background. Economic research has also highlighted potential links between housing wealth and entrepreneurial activity ${ }^{3}$. In crosssection any association between financial resources and self-employment is complicated by problems of endogeneity. Thus recent studies have examined the role of windfall financial gain in relaxing the capital constraints faced by potential entrepreneurs. A fuller discussion of these relationships is to be found in the literature on transitions into self-employment or entrepreneurship, with evidence for capital constraints found by, inter alia, Bates (1995), Evans and Leighton (1989), Evans and Jovanovic (1989) and Georgellis et al. (2005). However Hurst and Lusardi (2004) find that any correlation is only at very high levels of wealth. ${ }^{4}$ Disney and Gathergood (2009) conclude that inheritances, past and future, and house price shocks both act as poor instruments for the effect of potential capital constraints on entry into self-employment. 
Regional variation in entrepreneurial culture and in rates self-employment has been extensively discussed in the literature. Official data reveal varying rates of self-employment across UK regions with high rates in the South and low rates in the North of England. ${ }^{5}$ Regional variation may exist because levels of economic activity vary regionally and so market potential for new ventures is variable (Rotefoss and Kolvereid 2005). On the other hand areas of more volatile economic activity may have higher levels of transition into selfemployment because alternatives in salaried occupations are less plentiful. Variations in regional industrial structure may also affect levels of entrepreneurial activity, as well as variations in economic geography (clustering, urbanisation, agglomeration). For example Bates (1995) points out that barriers, such as capital constraints, vary considerably across small business industry groups. Regional variation in cultural attitudes towards entrepreneurship has also been identified. Davidsson (1995), for example, has addressed the significance of this in the Swedish context. Popular discussion often asserts that entrepreneurial 'spirit' is stronger in some regions of the UK than in others. ${ }^{6}$ This may be where levels of economic activity are higher (or perhaps because it is higher). In regions of the UK such as the North East of England and South Wales the legacy of former coal-mining and iron and steel industries has left communities with a strong 'collectivist' culture where the desire to 'branch-out on your own' may be viewed less positively. A final concern is government policy towards entrepreneurship. Small business support within the UK is devolved to regional governments in Scotland, Wales and Northern Ireland. Even within England regional variation in the interpretation and implementation of policy may vary because of different approaches taken by different regional development agencies.

This discussion highlights the need for any empirical investigation of selfemployment dynamics to condition appropriately for a wide range of individual background 
and external environmental influences. Many of these may potentially be associated with the adjustment costs that an individual will face when contemplating any decision to switch occupation.

\section{Modelling approach}

The discussion outlined above outlines a model in which the existence of (irreversible) adjustment costs leads to threshold behaviour on the part of an individual considering the decision to switch occupation. The threshold at which a switch becomes attractive is above the point where expected income in the new occupation (in this case selfemployment) exceeds expected income from remaining in the current occupation or state. The extent to which it is above will depend on switching costs associated with the degrees of risk in the incomes of each state. A formal model is described in Parker (1997), and leads to the specific proposition that if the expected income growth rate in entrepreneurship is higher than that in the alternative economic state (employment in Parker's model), and if there is no income uncertainty in that alternative state, then greater income risk in entrepreneurship will unambiguously reduce the fraction of time chosen to be spent in entrepreneurship. Attempts to investigate a relationship between an investment decision and switching costs have typically examined cross-sectional correlation between some measure of uncertainty and the scale of the investment (see Carruth et al., 2000 for a survey). However, the key empirical issue is not about the relationship between level of investment (or commitment to entrepreneurship) and the size of potential switching costs, but between the length of time between the framing of the choice and the decision itself. ${ }^{7}$ 
The approach adopted here is therefore to investigate the duration between initial expression of entrepreneurial aspiration and the decision to switch occupation into selfemployment. This is done by modelling the conditional hazard of a spell of entrepreneurial aspiration. The hazard in this case is the likelihood at any point that a particular aspiring entrepreneur will transition into self-employment. Estimation is performed using a discretetime duration approach developed by Prentice and Gloeckler (1978) and Meyer (1990). Practical implementation is provided by Jenkins (1995). The entrepreneurial aspiration spell of each individual, $\mathrm{i}=1, \ldots, \mathrm{n}$, is delimited in elapsed time, $\mathrm{t}$, in years. At the point at which an entrepreneurial aspiration is first stated $t=\tau$. If the individual subsequently transitions into self-employment we denote the length of the current spell by $s_{i}$, so $t=\tau+s_{i}$ denotes the time point of the spell end. If no transition is observed then $s_{i}$ denotes the point at which the spell is censored.

The discrete-time hazard rate, the probability that the aspiration spell ends at $t$ conditional on lasting until that point, is denoted by:

$$
\mathrm{h}_{\mathrm{it}}=\operatorname{prob}\left(\mathrm{T}_{\mathrm{i}}=\mathrm{t} \mid \mathrm{T}_{\mathrm{i}} \geq \mathrm{t} ; \mathbf{X}_{\text {it }}\right)
$$

where $T_{i}$ is a discrete random variable describing the time at which the end of the spell occurs, and $\mathbf{X}_{\mathrm{it}}$ is a vector of control covariates which may be time-varying. We assume that if an individual does not transition into self-employment at any point in time that their aspiration towards entrepreneurship continues. Define an indicator variable $y_{\text {it }}$ which equals 1 if $t=\tau+s_{i}$ and the current spell ends and 0 otherwise. Jenkins (1995) shows that the loglikelihood function is: 


$$
\log L=\sum_{\mathrm{i}=1}^{\mathrm{n}} \sum_{\mathrm{t}=\tau}^{\tau+\mathrm{si}_{\mathrm{i}}} \mathrm{yit}_{\mathrm{it}} \cdot \log \left[\mathrm{h}_{\mathrm{it}} /\left(1-\mathrm{h}_{\mathrm{it}}\right)\right]+\sum_{\mathrm{i}=1}^{\mathrm{n}} \sum_{\mathrm{t}=\tau}^{\tau+\mathrm{Si}_{\mathrm{i}}} \log \left(1-\mathrm{h}_{\mathrm{it}}\right)
$$

This likelihood function has the same form as that for a binary dependent variable model and can be easily estimated using standard maximisation techniques. Estimation now only requires the specification of a data generating process for $h_{i t}$. If $h_{i t}$ is determined as a discrete time counterpart to an underlying continuous time proportional hazards model then the appropriate functional form is a complementary log-log (extreme value) function:

$$
\mathrm{h}_{\mathrm{it}}=1-\exp \left[-\exp \left[\theta(\mathrm{t})+\beta \mathbf{X}_{\mathrm{it}}\right]\right]
$$

$\theta(\mathrm{t})$ provides the parameterisation of the baseline hazard. A parametric form can be assumed such as a Weibull where $\theta(\mathrm{t})=\log (\mathrm{t})$, or a flexible "semi-parametric" form where $\theta(\mathrm{t})$ is captured through a set of elapsed time intercept dummy variables.

Equation 3 can be extended to incorporate unobserved heterogeneity ('frailty') in the form of individual random effects:

$$
\mathrm{h}_{\mathrm{it}}=1-\exp \left[-\exp \left[\theta(\mathrm{t})+\beta \mathbf{X}_{\mathrm{it}}+v_{i}\right]\right]
$$

Where $\mathrm{v}_{\mathrm{i}}$ is an unobserved individual-specific error component with a zero mean which is uncorrelated with $\mathbf{X}$. For estimation purposes $\mathbf{v}_{\mathrm{i}}$ is assumed to follow a normal distribution, with estimation undertaken using the random effects complementary log-log estimation routine available in Stata version 10. 


\section{Data}

The empirical analysis in this paper draws on a major British social science research resource - namely the British Household Panel Survey (BHPS). This is a nationally representative survey funded by the UK Economic and Social Research Council, designed as a general purpose survey similar in structure to the US Panel Study of Income Dynamics and the German Socio-Economic Panel. A stratified random cluster sample of households is drawn from the population of British household postal addresses in Great Britain. ${ }^{8}$ The original household sample was recruited in 1991, and follow-on rules are established to track newly forming households involving originally-enumerated household members. ${ }^{9}$ The survey instrument is a questionnaire involving a household section, containing questions on housing and household structure, and sections administered to all adult household members (including new household members at each wave). The individual section contains a core of 'modules' covering demography and fertility, education, employment, health and finances, along with a rotating set of questions on values and opinions. Households are re-interviewed annually.

For empirical purposes entrepreneurship is defined by self-employment status. Selfemployment in the UK is defined by tax status - that is registered with the tax authority as an own-account worker or business owner with approval to pay income tax (and social security contributions) through an end of year assessment, rather than through the UK pay check deduction system known as 'Pay-As-You-Earn' (PAYE). The BHPS identifies selfemployment on this basis. ${ }^{10}$ An individual with multiple employments may hold one job for which tax is deducted through PAYE, and operate a business or own-account employment (self-employment) through which tax is assessed on an annual basis. For our purposes an individual transitions into self-employment either by switching from organisational (PAYE) 
employment to self-employment, or by newly registering as self-employed in addition to holding an established organisational employment.

From Wave 8 (1998) onwards all adults who are economically active are asked about entrepreneurial aspirations, as part of a prospective question concerning career plans. The precise wording is as follows:

'(E101) I am going to read out a list of things which you may or may not want to happen to your current employment situation. For each one can you please tell me whether you would like this to happen to you in the next twelve months. Would you like to ... start up you own business (a new business)?’

The response to this question identifies entrepreneurial aspiration. We define a successful start-up as one which results in the individual transitioning into full-time or part-time selfemployment. Although the question is defined in terms of a time frame of 12 months, it is quite likely that for some individuals it make take longer for a new business venture to be established, and for many no new venture may be created (at least up to the last available survey wave). However, they may continue to answer 'yes' to the aspiration question when it is repeated in the following wave. We interpret the responses to this question as indicating well-formed entrepreneurial aspiration, but that many individuals may be optimistic about achieving a switch in occupation within the specified 12 months. At the time of this research, up to eight subsequent annual observations of occupational status from Wave 9 (1999), up to Wave 16 (2006) are available for each individual. This allows us to construct a sample of spells of aspiring entrepreneurship from individual first annual observation of a desire to start up a new business, through either to transition to self-employment (uncensored spells) or to the final wave if no transition has taken place (censored spells). 
Table 1 describes the sample structure. This begins in 1999 with a total of 498 new aspiring entrepreneurs (who answered 'yes' to question 'E101' above, but 'no' in 1998). 127 of these individuals transitioned into self-employment in the first year. After one year 341 of these are still aspiring to start a new business venture and a further 17 transitioned into selfemployment - with the remainder either no longer aspiring or no longer in the survey. ${ }^{11}$ Even after seven years have elapsed 214 are still aspiring to start a new venture. Over the seven available waves a total of 194 from 498 aspiring entrepreneurs are known to have transitioned into self-employment. In order to increase the available number of aspiration spells, new aspirers in 2000 and subsequent annual waves up to 2006 are also included. In 2000, from a total of 379 new aspirers, 145 transition into self-employment, the majority in the first year. It is evident from Table 1 that rates of transition are around $40 \%$ as a proportion of the total numbers of aspiring entrepreneurs at the start of each sequence. It is also evident that the likelihood of transition is much higher in the first year after stating an aspiration than in subsequent years. In other words, the probability of transition, conditional of remaining an aspiring entrepreneur up to that point, drops quickly.

The second panel in Table 1 repeats the same descriptive exercise for the sub-sample of individuals who aspire to entrepreneurship from a state of economic activity (i.e. paid employment), and excludes around 27 percent of spells relating to those who aspire or transition to self-employment from inactivity (including unemployment, long term illness and from retirement). Overall rates of transition for the economically active are a little lower at around one third. 
Table 2 documents descriptive information on the range of covariates that will be investigated. The choice of covariates is informed by the discussion in section 2 above. The sample information relates to the pooled discrete individual-year observations on each spell of entrepreneurial aspiration. This yields a total pooled sample of 7139 individual-year observations, although this number is reduced to 6293 if the sample is restricted to spells relating to those who are economically active. There is little change in the covariate means from restricting the sample. A particular strength of the discrete hazard modelling approach is that it allows covariates to vary over time (if applicable) as well as across individuals. A fivefold broad regional categorisation is used. 45 per cent of the sample in located in the base region of the South of England. The distribution of observations on aspiring entrepreneurs across the regions is broadly in line with that of the general population. Mean age (timevarying) is 38 years. 44 percent of the sample observations are for women and 13 percent for members of minority ethnic groups. Marital status is time-varying. 20 percent of observations are for individuals who are single, never married (base category). 72 percent are for married or co-habiting individuals. This high proportion reflects the greater level of entrepreneurial aspiration amongst married individuals than in the general population. 47 per cent of observations are for individuals with dependent children (defined as aged 18 or below).

The individual's highest education qualification is categorised at four levels above no formal qualifications. The lowest category, O-Levels/GCSEs, denotes examinations passed at age 16 attempted at around the earliest point that an individual may currently leave compulsory schooling. ${ }^{12}$ This is the most common category comprising 36 per cent of the sample. The next category, A-levels, are attempted at age 18 as pre-qualifying examinations for higher education. ${ }^{13} 25$ per cent of the sample reached this level. Higher education qualifications are divided into two categories, which together account for around 27 per cent 
of sample observations. The first captures all higher education qualifications below bachelor's degree, including vocational qualifications such as the Higher National Diploma (HND). The second tertiary education qualification category is bachelor's degree. ${ }^{14}$

In order to assess family and personal background influences, we firstly use selfreported information in the BHPS on the employment activity of both parents when each respondent was 14 years of age. Two indicators are constructed. The first captures whether either of the respondent's parents were self-employed. 16 per cent of observations on aspiring entrepreneurs are for individuals who had self-employed parents. The second variable captures whether parents were self-employed and employed other people. 9 per cent of observations had employer parents. Two further indicators capture the economic status of the individual's partner, if they had one, at the previous wave. $47 \%$ of the sample has a partner who was in paid employment, and a further 7 per cent has a partner who was in selfemployment. The final indicator under this grouping is a binary variable capturing whether the individual had experienced any previous spells of self-employment during the period back to the start of the BHPS in 1991. Over 17 per cent of sample observations are for aspiring entrepreneurs who indicate that that they have previously been self-employed.

The BHPS contains a rich set of information on individual and household financial status. The covariate included in Table 2 is a continuous time-varying measure of household annual investment income. This is lagged one year to reduce any potential problem of endogeneity. The distribution is heavily skewed around a mean of $£ 469$ ( $£ 488$ for the economically active sub-sample), and the high standard deviation is consistent with the skewness. 
Two indicators of economic uncertainty or shocks are investigated. The first is an indicator of local volatility in the housing market, constructed as a moving three year standard deviation in the detrended real house price in the county in which the individual is resident. ${ }^{15}$ This is intended to capture volatility in average wealth levels in the locality and therefore consumer demand, and in the value of potential business start-up collateral. The second indicator is a time-varying measure of volatility in the local (county-level) unemployment rate, also constructed as a moving three year standard deviation. This is also intended to capture information about the volatility of local demand conditions.

The majority of aspiring entrepreneurs are in employment at the point at which initial aspiration is stated (88 per cent of sample observations). The remainder are categorised into two other possible states of economic inactivity - unemployment or inactivity ${ }^{16}$ (10 per cent), or long term sickness (2 per cent).

Finally, for the economically active in employment when entrepreneurial aspirations are observed, the BHPS provides information on job satisfaction over various dimensions, and a statement of preference over hours of work. These are included to capture the extent to which current experience in paid employment affects the speed with which aspiring entrepreneurs transition into self-employment. Answers to the job satisfaction questions are on a centred Likert scale from 1 (completely dissatisfied) to 7 (completely satisfied), and the variables are time-varying. Mean scores are lowest for satisfaction with pay, and highest for satisfaction with job security. This finding accords with previous research that suggests that aspiring entrepreneurs entertain exaggerated expectations about the financial returns to a new business venture (Arabsheibani et al., 2000; Fraser and Greene, 2006). The variables for preference on hours of work are binary, and are time-varying. Across the sample, for 37 per 
cent of observations aspiring entrepreneurs would like to work less hours; whereas only 7 per cent would like to work more. Again this suggests that aspiring entrepreneurs entertain highly unrealistic notions about the time commitment required to establish a successful new venture.

\section{Econometric Results}

Table 3 presents the results for various specifications of the econometric estimation of the discrete time duration model, described in equations 3 and 4 . Column 1 reports a simple flexible baseline model with no covariates and no modelling of unobserved heterogeneity for the full sample of aspiring entrepreneurs, both economically active and inactive at the point at which aspiration is first expressed. The individual baseline segments capture the effect of discrete annual increments in elapsed time since the initial expression of entrepreneurial aspiration. ${ }^{17}$ Each segment coefficient is highly statistically significant. However it is the pattern of coefficients that is of greater interest, since they fall significantly in size between elapsed years zero and one, and then continue to fall but at a slower rate until elapsed year 5. In other words the conditional probability of transitioning into self-employment from a spell of entrepreneurial aspiration falls very quickly. Between 5 and 7 the hazard rate rises slightly, although this may not be particularly significant. Column 2 reports the same model with no covariates, but with the inclusion of unobserved heterogeneity (random effects). Although the baseline coefficients change a little, the shape of the baseline is very similar, and in fact the rho parameter, which estimates the proportion of total model variance explained by the individual-specific error component (random effects), is not statistically significant in this simple model. 
Figure 1 plots the baseline hazard function computed for the model in column 2 and selected subsequent models. According to the model in column 2, in the current year, after initial expression of entrepreneurial aspiration, the conditional probability of transition is 26 percent. After one year it drops to just under 5 percent and then declines gradually over successive years to 2.4 percent, rising very slightly after 5 years of unfulfilled aspiration.

Columns 3 and 4 in Table 3 report estimates of a model which includes a full range of control variables for region, demographic and family background, educational background and financial resources. Column 3 reports estimates for the full sample of aspiration spells. Column 4 reports estimates for the sub-sample of those who are economically active at the time that a desire to start a new business is first stated. The coefficient estimates reveal that regional differences in the conditional hazard rate are generally not significant. Only individuals in the north of England have a significantly lower hazard rate, other things equal, compared to the base of the south of England. Turning to the demographic associations, the results show that older individuals have a significantly higher hazard rate $^{18}$, and that women have a significantly lower hazard rate. Evidence of higher occupational switching costs for women is consistent with generally much lower rates of self-employment for women in the population. The conditional probability of switching to self-employment in the first year is, other things equal, reduced from 18.4 per cent to 14.2 percent for a woman. These switching costs do not appear to be related to the presence of dependent children in the household, and may therefore be related to factors other than other family responsibilities, such as attitude to risk. However the conditional hazard rate is significantly higher for individuals who are married, and suggests that switching costs are lower where the household contains more than one potentially economically active adult. Despite previous research which documents the increased likelihood of self-employment amongst ethnic minorities, there is no significant 
difference in the hazard rate. Educational attainment, particularly at higher levels, appears to be associated with a higher hazard rate (or lower switching costs). However this association is only statistically significant for degree level qualifications in the case of the economically active. Degree holders may be better equipped to transition quickly into self-employment, although this may be as much to do with the acquisition of particular professional skills, and ability to negotiate successfully through the financial and legal formalities of launching a business, rather than higher education providing improved opportunities to acquire entrepreneurial skills. The conditional probability of transitioning to self-employment rises from 18.4 per cent to 23.5 per cent if the reference individual's highest qualification changes from A-level to university degree.

Turning now family and personal background there is no evidence that aspiring entrepreneurs with a parental background in entrepreneurship switch significantly more quickly into self-employment. Individuals whose spouse was employed at the previous wave have a statistically significantly lower hazard rate. Individuals whose spouse was selfemployed have a higher switching probability in column 3 but not in column 4 . This suggests that it is relatively easier for the economically inactive to join an existing business which is being run by their spouse. It also suggests that transition into entrepreneurship is encouraged by an entrepreneurial culture in the household and discouraged by its absence. Experience of previous spells of self-employment is strongly positively associated with a higher switching probability. Having had one or more previous spells of self-employment raises the conditional probability in the first year from 18.4 per cent to 30 per cent. Finally investment income has a positive coefficient but is not statistically significant, suggested that there is little or no relationship between switching costs and financial wealth. ${ }^{19}$ Once all these 
covariates are included in the model unobserved heterogeneity becomes quantitatively important and statistically significant, as indicated by the reported estimate of rho.

Column 5 of Table 3 reports a simplified specification, extracting those covariates which are found to be statistically significant in column 4. In some cases model simplification increases the size and significance of the remaining coefficient estimates. This model also additionally includes the two chosen indicators of local economic uncertainty, moving standard deviations of local house prices and unemployment rates. Both attract negative coefficients. However, only the coefficient on house price volatility is statistically significant, in this case at 6 per cent. Column 6 reports the same model, but excludes local unemployment volatility in order to reduce the impact of any collinearity between the two measures. Column 6 therefore represents our preferred specification. Here the coefficient estimate for the impact of house price uncertainty is a little larger and its statistical significance improves to 4 per cent. This result is fully consistent with theoretical predictions - namely that greater volatility in local economic conditions appears to be associated with higher switching costs and therefore slows down the rate at which aspiring entrepreneurs switch into self-employment. Figure 1 shows that the estimated initial conditional probability of transition to self-employment is rather lower than in the model with no covariates. In the first year the conditional probability of transition for the reference individual is 14.9 per cent, falling to 3.4 per cent after a further year, and reaching minimum of 1.4 per cent after five elapsed years. In column 6 a one standard deviation in the increase in volatility of local house prices lowers the conditional probability of transition to self-employment for the reference individual from 14.9 per cent to 13.6 per cent. 
Column 7 of Table 3 reports a full model specification which includes lagged information on job satisfaction, in order to investigate the proposition that those who are less satisfied with current paid employment may transition more rapidly into self-employment. In other words such individuals may be those for whom the perceived value of the foregone alternative (paid employment) is lower and therefore have lower switching costs. We would expect higher job satisfaction to be associated with a lower conditional probability of transition to self-employment and therefore that the job satisfaction variables would attract a negative coefficient. This is the case for satisfaction with job security, where the negative coefficient is statistically significant at the level of 8 per cent (7 per cent in column 8 where a simplified specification is presented). However for the other dimensions of job satisfaction, pay and work, there is no significant relationship. There is also no significant relationship between the desire to work different hours, either more or less, and the hazard rate. The coefficient signs are as might be expected if individuals perceive that launching a new business venture will require longer hours of work - a lower hazard rate for those who wish for fewer hours and a higher one for those who would like to work more.

\section{Conclusions}

The decision to switch occupation into entrepreneurship (self-employment) is one which is characterised by uncertainty about future income streams and for which there may be substantial irrecoverable switching costs. There has been little or no previous empirical research on the extent to which switching costs impact on the transition decision of aspiring entrepreneurs, nor on the extent to which modelled or unobserved heterogeneity amongst aspiring entrepreneurs affects the conditional probability of that transition. This paper has approached this issue by investigating econometrically the determinants of the conditional 
probability that a spell of entrepreneurial aspiration will end with an occupational switch into self-employment. The data source used is from the UK's longitudinal household survey, which has since 1998 asked individual adult respondents a question about entrepreneurial aspiration. While general purpose survey data may not contain the level of specific detail (such as information on cognitive characteristics) that might ideally be required, the use of longitudinal data allows a full analysis of the dynamics of transition.

The paper finds a number of significant demographic associations with the speed at which aspiring entrepreneurs transition into self-employment, particular age, gender and higher levels of educational attainment. For men, older individuals and those with more education occupational switching costs appear to be lower, and this is consistent with the significant body of empirical work which finds, other things equal, higher probabilities of self-employment for these groups. There are clear policy implications here - interventions to assist women and less educated individuals prepare for entrepreneurship may improve their representation amongst the self-employed. However, no evidence is found for a different hazard rate for ethnic minorities. These may be because our data source is insufficiently large to allow identification of differences between different ethnic minority groups. But the finding may indicate that there is no significant difference in the costs of entering entrepreneurship for ethnic minorities.

Some aspects of household and individual background are also found to be associated with the speed of transition into self-employment. There are two principal findings here. The first is that the absence of entrepreneurial 'culture' in the household is associated with slower transition. This seems a straightforward finding - namely that aspiring entrepreneurs who are less able to draw on the expertise of self-employed spouses will have high switching costs. 
However, although previous research has observed a relationship between parental background and choice of self-employment, this research finds no evidence that aspiring entrepreneurs with a strong entrepreneurial parental background transition more quickly into self-employment. Previous experience of self-employment appears to have a strong positive effect on the speed with which an individual transitions into self-employment. This is perhaps not surprising and suggests that for the majority prior experience of self-employment is a positive one and imbues a greater sense of confidence about starting a new business venture. Prior personal experience of entrepreneurship is therefore associated with lower switching costs. Policies to provide mentoring arrangements for aspiring first-time entrepreneurs may reduce perceived switching costs and serve to mitigate this difference between novice and serial entrepreneurs.

One final important conclusion to emerge from the paper is that an indicator of local volatility in the housing market is significantly associated with speed of transition. A one standard deviation increase in house price volatility reduces the conditional probability of transition into self-employment by 1.3 percentage points. Uncertainty about local economic conditions may increase the costs of switching occupation. This finding is consistent with the notion that the timing of transitions depends on perceptions about the level of uncertainty attached to the profitability of a future business venture. It may also indicate the effect of housing market volatility on the way in which aspiring entrepreneurs frame the impact of any downside risk associated with launching a new business. While substantial empirical research has addressed this issue of the relationship between investment and uncertainty in the context of corporate investment decisions, no previous research has identified such an effect in the context of individual decisions about occupational choice. This is surprising because the availability of longitudinal data providing information (albeit in a discretised form) on the 
timing of the decision is ideally suited to analysis. This is because the underlying theoretical considerations relate to the timing rather than the scale of the investment. In the current conditions of global economic turmoil and, in the case of the UK, a rapid collapse in confidence in the housing market, this result points to an important transmission mechanism which may weaken entrepreneurial creativity in the economy. 


\section{Footnotes}

\footnotetext{
${ }^{1}$ For an excellent survey see Parker (2004), especially Chapter 2.

${ }^{2}$ See Shook et al. (2003) for a recent literature review and synthesis. Gartner (1985) provides an important early discussion of conceptual issues underpinning nascent entrepreneurship.
}

${ }^{3}$ Some economic analysis reports associations between self-employment rates and housing wealth (for example Black et al., 1996; Henley, 2004).

${ }^{4}$ Georgellis et al. (2005) provide a survey of this literature and further highlights a lack of consensus. They also conduct their own research on the impact of financial windfalls on the transition to self-employment using the same data survey as used in this paper. They conclude that while inheritances raise the probability of transition, lottery wins lower it.

${ }^{5}$ According to official labour force survey data from the UK Office for National Statistics the rate of self-employment in Spring 2005 was 9.8\% of the working age population. However this rate varied from only 5.6\% in the North East 'Government Office' region of England to $12 \%$ in the South East region of England. Rates for Scotland and Wales were below the UK average at 7.4\% and 8.8\% respectively (source: Regional Trends, issue 39, May 2006, UK Office for National Statistics).

${ }^{6}$ Tamasy (2006) investigates variation in regional entrepreneurial dynamics in Germany and concludes that public policy should pay attention to regional variation in attitudes towards entrepreneurship.

${ }^{7}$ The only empirical work, in the context of investment and uncertainty, which looks at this time duration issue is in the context of the discovery of North Sea oil reserves (see Hurn and Wright, 1994; Favero et al., 1994)

8 The far north of Scotland is excluded because of the prohibitive sampling costs. The original survey excludes Northern Ireland. Booster samplers for Wales and Scotland recruited in 1999 and a sample for Northern Ireland recruited in 2001 are excluded from the analysis. Technical details are provided in Taylor et al. (2004) and Lynn (2006).

${ }^{9}$ Sample attrition rates in the BHPS are generally low and certainly comparable to those achieved in other similar household panels. As is typical with household panels the highest attrition rate of individuals was between Waves 1 and 2 (12\%). Attrition between Waves 2 and 3 was $7 \%$ of the original individuals and subsequently averaged $2.4 \%$ of the original sample between waves. In common with nearly all previously published research using this data source, we treat attrition as a random event.

${ }^{10}$ For those whose main occupation is self-employment, the survey provides some further information on the type of self-employment. Between 1998 and 2002 between 38 and 40 per cent of the self-employed were running or in partnership in a business or professional practice. A further 40 to 43 per cent were own-account workers, with the remainder working as freelancers, subcontractors or other unspecified categories of self-employment. These categorizations are self-reported and therefore dependent on the manner in which respondents interpret the categories. 
${ }^{11}$ This may be because of non-response to follow-on waves, but as noted above, attrition rates in the later waves of the BHPS are generally very low.

${ }^{12}$ Schooling is current compulsory in the UK to age 16 . The age was raised from 15 in the early 1970s. Older respondents would therefore have had the opportunity to leave school a year prior to these examinations. Until the late 1980s students took either 'O-level' examinations or 'Certificate of Secondary Education' (CSE) examinations. Subsequently an integrated system of 'General Certificates of Secondary Education' (GCSE) was introduced.

13 These courses are taught in either schools ('sixth form') or in further education sectors colleges. A-levels are formal examinations - the category used in the analysis also includes other vocational qualifications taken for higher education pre-qualifying, which are deemed to be equivalent to A-levels.

${ }^{14}$ All those with postgraduate degrees (masters or doctorate) are assumed previously to have achieved a bachelor's degree.

${ }^{15}$ County house price data is obtained from the regular survey data reported by HBOS plc (formerly the Halifax Building Society; www.hbosplc.com). The data are for the average selling price of a semi-detached house. Detrending is performed by using the residuals from a regression of real house prices on a series of year dummy variables.

${ }^{16}$ Preliminary analysis was conducted using a further three way breakdown of inactivity into withdrawal from the labour force, self-reported retirement, and an other category capturing other forms, including full-time education and caring for dependents. No statistically significant difference between the hazard rates of these groups was found.

17 The zero elapsed years dummy captures the hazard rate in the first twelve months. Any aspiration spell which ends during this period is one in which the individual is observed to have transitioned into self-employment between the point of first stating an entrepreneurial aspiration and the next wave of the panel.

${ }^{18}$ Initial empirical analysis investigated the inclusion of a quadratic in age to identify a nonlinearity in the relationship between transition and age (or indirectly experience). None was found.

${ }^{19}$ Preliminary analysis investigated the potential role of a number of indicators of the financial resources of aspiring entrepreneurs, including indicators of active saving and personal housing wealth, but found no significant association with transition into selfemployment. 


\section{References}

Arabsheibani, G., de Meza, D., Maloney J. and Pearson, B. 2000 'And a vision appeared unto them of a great profit: evidence of self-deception among the self-employed'. Economics Letters, 67: 35-41.

Bates, T. 1995 'Self-employment entry across industry groups'. Journal of Business Venturing 10: 143-156.

Blanchflower, D.G. 2000 'Self-employment in OECD countries'. Labour Economics 7:471505.

Carroll, G.R. and Mosakowski, E. 1987 'The career dynamics of self-employment'. Administrative Science Quarterly 32: 570-589.

Carruth, A., Dickerson, A. and Henley, A. 2000 'What do we know about investment under uncertainty’. Journal of Economic Surveys 14:119-54.

Clark, K. and Drinkwater, S. 2000 'Pushed in or pulled out? Self-employment among ethnic minorities in England and Wales’. Labour Economics, 7: 603-28.

Davidsson, P. 1995 'Culture, structure and regional levels of entrepreneurship'. Entrepreneurship and Regional Development, 7: 41-62

Delmar, F. and Davidsson, P. 2000 'Where do they come from? Prevalence and characteristics of nascent entrepreneurs'. Entrepreneurship and Regional Development 12:123.

de Wit, G. and van Winden, F.A.A.M., 1989 'An empirical analysis of self-employment in the Netherlands’. Small Business Economics 1:263-272.

Disney, R. and Gathergood, J. 2009 'Housing wealth, liquidity constraints and selfemployment’. Labour Economics (in press, doi:10.1016/j.labeco.2008.05.002 )

Dixit, A. K. and Pindyck, R. S. 1994 Investment under Uncertainty (Princeton: Princeton University Press).

Dixit, A.K. and Rob, R. 1994 'Switching costs and sectoral adjustments in general equilibrium with uninsured risk’, Journal of Economic Theory, 62: 48-69.

Dunn, T. and Holtz-Eakin, D. 2000 'Financial capital, human capital and the transition to self-employment: evidence from intergenerational links'. Journal of Labor Economics, 18: 282-305

Evans, D.S. and Jovanovic, B. 1989 'An estimated model of entrepreneurial choice under liquidity constraints’. Journal of Political Economy 97:808-827.

Evans, D.S. and Leighton, L.S. 1989 'Some empirical aspects of entrepreneurship'. American Economic Review 79: 519-535.

Fairlie, R.W. and Meyer, B.D. 1996 'Ethnic and racial self-employment: differences and possible explanations’, Journal of Human Resources, 31:757-93. 
Favero, C.A., Pesaran, M. H. and Sharma, S. 1994 'A duration model of irreversible investment: theory and empirical evidence’, Journal of Applied Econometrics, 9, S95-S112.

Fraser, S. and Greene F.J. 2006 'The effects of experience on entrepreneurial optimism and uncertainty’. Economica, 72: 169-192.

Gartner, W.B. 1985 'A conceptual framework for describing the phenomenon of new venture creation’. Academy of Management Review 10:696-706.

Gartner W.B., Shaver, K.G., Carter, N.M. and Reynolds, P.D. (eds.) 2004 Handbook of Entrepreneurial Dynamics (Sage: Thousand Oaks).

Georgellis, Y., Sessions, J.G. and Tsitsianis, N. (2005), 'Windfalls, wealth and the transition to self-employment'. Small Business Economics 25:207-428.

Hammarstedt, M. 2004 'Self-employment among immigrants in Sweden - an analysis of intergroup differences’. Small Business Economics 23:115-126

Henley, A. 2004 'Self-employment status: The role of state dependence and initial conditions’, Small Business Economics 22: 67-82

Henley, A. 2007 'Entrepreneurial aspiration and transition into self-employment: evidence from British longitudinal data’. Entrepreneurship and Regional Development 19: 253-280

Hurn, A. S. and Wright, R. E. 1994 'Geology or economics? Testing models of irreversible investment using North Sea Oil Data’, Economic Journal, 104, 363-71.

Hurst, E. and Lusardi, A. (2004) 'Liquidity constraints, household wealth and entrepreneurship', Journal of Political Economy, 112:319-347.

Jenkins, S.P. 1995. 'Easy estimation methods for discrete-time duration models'. Oxford Bulletin of Economics and Statistics 57: 129-138.

Katz, J. 1990 'Longitudinal analysis of self-employment follow-through'. Entrepreneurship and Regional Development 2: 15-25.

Kolvereid, L. 1996a 'Organizational employment versus self-employment: reasons for career choice intentions’. Entrepreneurship Theory and Practice, 20:23-31.

Kolvereid, L. 1996b 'Prediction of employment status choice intentions'. Entrepreneurship Theory and Practice, 21:47-57.

Le, A. 1999 'Empirical studies of self-employment'. Journal of Economic Surveys 13:381416.

Lynn, P. (ed.) 2006. Quality Profile: British Household Panel Survey (Institute of Social and Economic Research, University of Essex: Colchester UK) http://www.iser.essex.ac.uk/ulsc/bhps/quality-profiles/BHPS-QP-01-03-06-v2.pdf (accessed 9/2/2007).

Meyer, B.D. 1990 'Unemployment insurance and unemployment spells'. Econometrica, 58:757-82. 
Parker, S.C. 1997 'The effects of risk on self-employment'. Small Business Economics 9: 515-22

Parker, S.C. 2004 The Economics of Self-Employment and Entrepreneurship (Cambridge University Press: Cambridge UK)

Prentice, R.L. and Gloeckler, L.A. 1978 'Regression analysis of grouped survival data with application to breast cancer data’. Biometrics 34: 57-67.

Rotefoss, B. and Kolvereid, L. 2005 'Aspiring, nascent and fledgling entrepreneurs: an investigation of the business start-up process'. Entrepreneurship and Regional Development, 17:109-127.

Shook, C.L., Priem, R.L. and McGee, J.E. 2003 'Venture creation and the enterprising individual: a review and synthesis'. Journal of Management 29:379-399.

Tamasy, C. 2006 'Determinants of regional entrepreneurial dynamics in contemporary Germany: a conceptual and empirical analysis’. Regional Studies, 40: 365-384.

Taylor, M.F. with Brice, J., Buck, N. and Prentice-Lane E. 2004 British Household Panel Survey User Manual Volume A: Introduction, Technical Report and Appendices (University of Essex: Colchester, UK).

Zissimopoulos, J.M. and Karoly, L.A. 2007 'Transitions to self-employment at older ages: the role of wealth, health, health insurance and other factors'. Labour Economics 14: 269295. 
Table 1: Entrepreneurial aspiration spells

a) all individuals

\begin{tabular}{|c|c|c|c|c|c|c|c|c|}
\hline & \multicolumn{8}{|c|}{ Spells beginning in: } \\
\hline Elapsed years: & 1999 & 2000 & 2001 & 2002 & 2003 & 2004 & 2005 & 2006 \\
\hline $\begin{array}{l}0 \text { : number aspiring } \\
\text { Number transitioning }\end{array}$ & $\begin{array}{l}498 \\
127\end{array}$ & $\begin{array}{l}379 \\
95\end{array}$ & $\begin{array}{l}294 \\
89\end{array}$ & $\begin{array}{l}263 \\
81\end{array}$ & $\begin{array}{l}248 \\
80\end{array}$ & $\begin{array}{l}267 \\
64\end{array}$ & $\begin{array}{l}216 \\
55\end{array}$ & $\begin{array}{l}202 \\
52\end{array}$ \\
\hline $\begin{array}{l}\text { 1: number aspiring } \\
\text { Number transitioning }\end{array}$ & $\begin{array}{l}341 \\
17\end{array}$ & $\begin{array}{l}265 \\
13\end{array}$ & $\begin{array}{l}192 \\
10\end{array}$ & $\begin{array}{l}164 \\
7\end{array}$ & $\begin{array}{l}145 \\
9\end{array}$ & $\begin{array}{l}186 \\
10\end{array}$ & $\begin{array}{l}136 \\
5\end{array}$ & \\
\hline $\begin{array}{l}\text { 2: number aspiring } \\
\text { Number transitioning }\end{array}$ & $\begin{array}{l}318 \\
13\end{array}$ & $\begin{array}{l}244 \\
10\end{array}$ & $\begin{array}{l}179 \\
10\end{array}$ & $\begin{array}{l}153 \\
9\end{array}$ & $\begin{array}{l}133 \\
7\end{array}$ & $\begin{array}{l}173 \\
5\end{array}$ & & \\
\hline $\begin{array}{l}\text { 3: number aspiring } \\
\text { number transitioning }\end{array}$ & $\begin{array}{l}287 \\
11\end{array}$ & $\begin{array}{l}227 \\
9\end{array}$ & $\begin{array}{l}162 \\
4\end{array}$ & $\begin{array}{l}136 \\
6\end{array}$ & $\begin{array}{l}117 \\
4\end{array}$ & & & \\
\hline $\begin{array}{l}\text { 4: number aspiring } \\
\text { number transitioning }\end{array}$ & $\begin{array}{l}258 \\
6\end{array}$ & $\begin{array}{l}206 \\
6\end{array}$ & $\begin{array}{l}144 \\
5\end{array}$ & $\begin{array}{l}126 \\
3\end{array}$ & & & & \\
\hline $\begin{array}{l}\text { 5: number aspiring } \\
\text { number transitioning }\end{array}$ & $\begin{array}{l}243 \\
9 \\
\end{array}$ & $\begin{array}{l}193 \\
4 \\
\end{array}$ & $\begin{array}{l}137 \\
4 \\
\end{array}$ & & & & & \\
\hline $\begin{array}{l}\text { 6: number aspiring } \\
\text { number transitioning }\end{array}$ & $\begin{array}{l}223 \\
5 \\
\end{array}$ & $\begin{array}{l}182 \\
8\end{array}$ & & & & & & \\
\hline $\begin{array}{l}\text { 7: number aspiring } \\
\text { number transitioning }\end{array}$ & $\begin{array}{l}214 \\
6\end{array}$ & & & & & & & \\
\hline Total transitions & 194 & 145 & 122 & 106 & 100 & 79 & 60 & 52 \\
\hline Total transitions (all) & 858 & & & & & & & \\
\hline
\end{tabular}


Table 1 (continued)

b) economically active individuals

\begin{tabular}{|c|c|c|c|c|c|c|c|c|}
\hline & Spells & ginnin & & & & & & \\
\hline Elapsed years: & 1999 & 2000 & 2001 & 2002 & 2003 & 2004 & 2005 & 2006 \\
\hline $\begin{array}{l}0: \text { number aspiring }^{1} \\
\quad \text { Number transitioning }^{2}\end{array}$ & $\begin{array}{l}418 \\
89\end{array}$ & $\begin{array}{l}313 \\
60\end{array}$ & $\begin{array}{l}244 \\
62\end{array}$ & $\begin{array}{l}228 \\
63\end{array}$ & $\begin{array}{l}219 \\
58\end{array}$ & $\begin{array}{l}226 \\
48\end{array}$ & $\begin{array}{l}191 \\
40\end{array}$ & $\begin{array}{l}167 \\
34\end{array}$ \\
\hline $\begin{array}{l}\text { 1: number aspiring } \\
\text { Number transitioning }\end{array}$ & $\begin{array}{l}321 \\
14\end{array}$ & $\begin{array}{l}255 \\
12\end{array}$ & $\begin{array}{l}181 \\
9 \\
\end{array}$ & $\begin{array}{l}158 \\
7\end{array}$ & $\begin{array}{l}138 \\
9\end{array}$ & \begin{tabular}{|l|}
180 \\
9 \\
\end{tabular} & $\begin{array}{l}131 \\
5\end{array}$ & \\
\hline $\begin{array}{l}\text { 2: number aspiring } \\
\text { Number transitioning }\end{array}$ & $\begin{array}{l}284 \\
11\end{array}$ & $\begin{array}{l}216 \\
8\end{array}$ & $\begin{array}{l}158 \\
7 \\
\end{array}$ & $\begin{array}{l}143 \\
6\end{array}$ & $\begin{array}{l}121 \\
6\end{array}$ & $\begin{array}{l}157 \\
5\end{array}$ & & \\
\hline $\begin{array}{l}\text { 3: number aspiring } \\
\text { number transitioning }\end{array}$ & $\begin{array}{l}258 \\
10\end{array}$ & $\begin{array}{l}199 \\
7\end{array}$ & $\begin{array}{l}142 \\
3\end{array}$ & $\begin{array}{l}125 \\
4\end{array}$ & $\begin{array}{l}103 \\
3\end{array}$ & & & \\
\hline $\begin{array}{l}\text { 4: number aspiring } \\
\text { number transitioning }\end{array}$ & $\begin{array}{l}231 \\
5 \\
\end{array}$ & $\begin{array}{l}179 \\
5 \\
\end{array}$ & $\begin{array}{l}127 \\
3 \\
\end{array}$ & $\begin{array}{l}116 \\
2\end{array}$ & & & & \\
\hline $\begin{array}{l}\text { 5: number aspiring } \\
\text { number transitioning }\end{array}$ & $\begin{array}{l}209 \\
5\end{array}$ & $\begin{array}{l}171 \\
2\end{array}$ & $\begin{array}{l}119 \\
2\end{array}$ & & & & & \\
\hline $\begin{array}{l}\text { 6: number aspiring } \\
\text { number transitioning }\end{array}$ & $\begin{array}{l}192 \\
2\end{array}$ & $\begin{array}{l}161 \\
5\end{array}$ & & & & & & \\
\hline $\begin{array}{l}\text { 7: number aspiring } \\
\text { number transitioning }\end{array}$ & $\begin{array}{l}183 \\
4\end{array}$ & & & & & & & \\
\hline Total transitions & 140 & 99 & 86 & 82 & 76 & 62 & 45 & 34 \\
\hline Total transitions (all) & 624 & & & & & & & \\
\hline
\end{tabular}

Source: computed from BHPS Waves 8-16

Notes:

${ }^{1}$ where the no. of elapsed years is zero this is the number of new aspiring entrepreneurs (i.e. those who did not state an aspiration in the previous year, but did state one in the current year and transitioned into self-employment in the current year.

${ }^{2}$ i.e. those transitioning in self-employment with no stated aspiration in the previous year. 
Table 2: Sample Descriptive Statistics

\begin{tabular}{|c|c|c|c|c|}
\hline \multirow[b]{2}{*}{ Covariate: } & \multicolumn{2}{|c|}{$\begin{array}{c}\text { All } \\
\mathrm{N}=7139\end{array}$} & \multicolumn{2}{|c|}{$\begin{array}{l}\text { Economically active } \\
\qquad \mathrm{N}=6293\end{array}$} \\
\hline & Mean & Std. Dev. & Mean & Std. Dev. \\
\hline Region: South of England (base) & 0.451 & & 0.453 & \\
\hline Midlands & 0.152 & & 0.153 & \\
\hline North of England & 0.271 & & 0.270 & \\
\hline Wales & 0.052 & & 0.051 & \\
\hline Scotland & 0.074 & & 0.073 & \\
\hline $\begin{array}{l}\text { Demographics: } \\
\text { Age (years) }\end{array}$ & 37.75 & 10.92 & 38.04 & 10.73 \\
\hline Female & 0.437 & & 0.420 & \\
\hline Minority ethnic & 0.134 & & 0.133 & \\
\hline Marital status: Single (base) & 0.205 & & 0.193 & \\
\hline Married/Co-habiting & 0.723 & & 0.737 & \\
\hline Separated/Divorced & 0.072 & & 0.070 & \\
\hline Dependent children & 0.467 & & 0.456 & \\
\hline $\begin{array}{l}\text { Highest educational level: } \\
\text { No school qualifications (base) }\end{array}$ & 0.122 & & 0.119 & \\
\hline O-levels/GCSEs (aged 16) & 0.357 & & 0.358 & \\
\hline A-levels (aged 18) & 0.249 & & 0.250 & \\
\hline Vocational higher qualification & 0.078 & & 0.081 & \\
\hline College/university degree & 0.194 & & 0.192 & \\
\hline $\begin{array}{l}\text { Family and personal background: } \\
\text { Self-employed parent (at age 14) }\end{array}$ & 0.162 & & 0.168 & \\
\hline $\begin{array}{l}\text { Self-employed parent who employed } \\
\text { others (at age 14) }\end{array}$ & 0.094 & & 0.097 & \\
\hline Partner employed (lagged) & 0.469 & & 0.488 & \\
\hline Partner self-employed (lagged) & 0.071 & & 0.067 & \\
\hline Previous spells of self-employment & 0.175 & & 0.179 & \\
\hline Investment income (£000s, lagged) & 0.452 & 2.324 & 0.440 & 2.128 \\
\hline $\begin{array}{l}\text { County house price, detrended } £ \mathrm{k} \text { (moving } \\
\text { std. dev.) }\end{array}$ & 1.331 & 2.324 & 1.327 & 0.930 \\
\hline County unemployment rate (moving std. dev.) & 0.273 & 0.217 & 0.271 & 0.216 \\
\hline $\begin{array}{l}\text { Economic status in previous year } \\
\text { Employed (base) }\end{array}$ & 0.881 & & 1.000 & \\
\hline Unemployed/inactive & 0.097 & & - & \\
\hline Long term sick & 0.022 & & - & \\
\hline Job satisfaction score - pay (lagged) $^{1}$ & - & & 4.749 & 1.536 \\
\hline 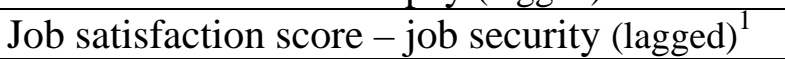 & - & & 5.320 & 1.526 \\
\hline $\begin{array}{l}\text { Job satisfaction score - nature of work } \\
\text { (lagged) }{ }^{1}\end{array}$ & - & & 5.197 & 1.404 \\
\hline Would like to work less hours (lagged) ${ }^{1}$ & - & & 0.373 & \\
\hline Would like to work more hours (lagged) ${ }^{1}$ & - & & 0.071 & \\
\hline
\end{tabular}

Source: computed from BHPS Waves 8-15

Notes: ${ }^{1} \mathrm{~N}=5688$ 
Table 3: Discrete-Time Duration Model Estimates

\begin{tabular}{|c|c|c|c|c|c|c|c|c|}
\hline & $(1)$ & $(2)$ & (3) & (4) & (5) & $(6)$ & (7) & $(8)$ \\
\hline Sample & All & All & All & $\begin{array}{l}\text { Econ } \\
\text { Active }\end{array}$ & $\begin{array}{l}\text { Econ } \\
\text { Active }\end{array}$ & $\begin{array}{l}\text { Econ } \\
\text { Active }\end{array}$ & $\begin{array}{l}\text { Econ } \\
\text { Active }\end{array}$ & $\begin{array}{l}\text { Econ } \\
\text { Active }\end{array}$ \\
\hline Model: Unobserved heterogeneity? & No & Yes & Yes & Yes & Yes & Yes & Yes & Yes \\
\hline $\begin{array}{l}\text { Semi-parametric baseline hazard: } \\
\text { Elapsed years: } 0\end{array}$ & $\begin{array}{l}-1.065 \\
(0.043) * *\end{array}$ & $\begin{array}{l}-1.190 \\
(0.152)^{* *}\end{array}$ & $\begin{array}{l}-2.748 \\
(0.457)^{* *}\end{array}$ & $\begin{array}{l}-2.444 \\
(0.444)^{* *}\end{array}$ & $\begin{array}{l}-2.453 \\
(0.412)^{* *}\end{array}$ & $\begin{array}{l}-2.565 \\
(0.410)^{* *}\end{array}$ & $\begin{array}{l}-2.263 \\
(0.462)^{* *}\end{array}$ & $\begin{array}{l}-2.467 \\
(0.434) * *\end{array}$ \\
\hline 1 & $\begin{array}{l}-2.946 \\
(0.119) * *\end{array}$ & $\begin{array}{l}-3.012 \\
(0.140) * *\end{array}$ & $\begin{array}{l}-4.354 \\
(0.409)^{* *}\end{array}$ & $\begin{array}{l}-3.997 \\
(0.405) * *\end{array}$ & $\begin{array}{l}-3.992 \\
(0.371) * *\end{array}$ & $\begin{array}{l}-4.096 \\
(0.369)^{* *}\end{array}$ & $\begin{array}{l}-3.805 \\
(0.447) * *\end{array}$ & $\begin{array}{l}-3.998 \\
(0.411)^{* *}\end{array}$ \\
\hline 2 & $\begin{array}{l}-3.139 \\
(0.144) * *\end{array}$ & $\begin{array}{l}-3.181 \\
(0.152) * *\end{array}$ & $\begin{array}{l}-4.478 \\
(0.396)^{* *}\end{array}$ & $\begin{array}{l}-4.245 \\
(0.399) * *\end{array}$ & $\begin{array}{l}-4.260 \\
(0.362)^{* *}\end{array}$ & $\begin{array}{l}-4.356 \\
(0.359)^{* *}\end{array}$ & $\begin{array}{l}-4.115 \\
(0.455)^{* *}\end{array}$ & $\begin{array}{l}-4.295 \\
(0.416) * *\end{array}$ \\
\hline 3 & $\begin{array}{l}-3.264 \\
(0.174)^{* *}\end{array}$ & $\begin{array}{l}-3.290 \\
(0.177)^{* *}\end{array}$ & $\begin{array}{l}-4.572 \\
(0.398)^{* *}\end{array}$ & $\begin{array}{l}-4.358 \\
(0.406)^{* *}\end{array}$ & $\begin{array}{l}-4.387 \\
(0.368)^{* *}\end{array}$ & $\begin{array}{l}-4.472 \\
(0.366)^{* *}\end{array}$ & $\begin{array}{l}-4.256 \\
(0.465)^{* *}\end{array}$ & $\begin{array}{l}-4.451 \\
(0.429) * *\end{array}$ \\
\hline 4 & $\begin{array}{l}-3.706 \\
(0.243) * *\end{array}$ & $\begin{array}{l}-3.718 \\
(0.244)^{* *}\end{array}$ & $\begin{array}{l}-5.005 \\
(0.431)^{* *}\end{array}$ & $\begin{array}{l}-4.744 \\
(0.443)^{* *}\end{array}$ & $\begin{array}{l}-4.784 \\
(0.407)^{* *}\end{array}$ & $\begin{array}{l}-4.852 \\
(0.407)^{* *}\end{array}$ & $\begin{array}{l}-4.634 \\
(0.502)^{* *}\end{array}$ & $\begin{array}{l}-4.824 \\
(0.466) * *\end{array}$ \\
\hline 5 & $\begin{array}{l}-3.496 \\
(0.250) * *\end{array}$ & $\begin{array}{l}-3.496 \\
(0.252)^{* *}\end{array}$ & $\begin{array}{l}-4.791 \\
(0.435)^{* *}\end{array}$ & $\begin{array}{l}-4.910 \\
(0.487)^{* *}\end{array}$ & $\begin{array}{l}-4.959 \\
(0.452)^{* *}\end{array}$ & $\begin{array}{l}-5.012 \\
(0.454)^{* *}\end{array}$ & $\begin{array}{l}-4.851 \\
(0.550)^{* *}\end{array}$ & $\begin{array}{l}-5.031 \\
(0.518) * *\end{array}$ \\
\hline 6 & $\begin{array}{l}-3.387 \\
(0.277)^{* *}\end{array}$ & $\begin{array}{l}-3.370 \\
(0.280)^{* *}\end{array}$ & $\begin{array}{l}-4.677 \\
(0.449)^{* *}\end{array}$ & $\begin{array}{l}-4.841 \\
(0.517)^{* *}\end{array}$ & $\begin{array}{l}-4.908 \\
(0.487)^{* *}\end{array}$ & $\begin{array}{l}-4.964 \\
(0.488)^{* *}\end{array}$ & $\begin{array}{l}-4.871 \\
(0.596)^{* *}\end{array}$ & $\begin{array}{l}-5.071 \\
(0.569) * *\end{array}$ \\
\hline 7 & $\begin{array}{l}-3.521 \\
(0.408) * *\end{array}$ & $\begin{array}{l}-3.488 \\
(0.414) * *\end{array}$ & $\begin{array}{l}-4.821 \\
(0.542)^{* *}\end{array}$ & $\begin{array}{l}-4.787 \\
(0.612)^{* *}\end{array}$ & $\begin{array}{l}-4.837 \\
(0.586)^{* *}\end{array}$ & $\begin{array}{l}-4.893 \\
(0.588)^{* *}\end{array}$ & $\begin{array}{l}-4.552 \\
(0.658) * *\end{array}$ & $\begin{array}{l}-4.724 \\
(0.632) * *\end{array}$ \\
\hline $\begin{array}{l}\text { Region (Base - South of England): } \\
\text { Midlands } \\
\end{array}$ & & & $\begin{array}{l}-0.020 \\
(0.146) \\
\end{array}$ & $\begin{array}{l}-0.165 \\
(0.140) \\
\end{array}$ & & & & \\
\hline North & & & $\begin{array}{l}-0.292 \\
(0.133)^{*}\end{array}$ & $\begin{array}{l}-0.220 \\
(0.132)+\end{array}$ & & & & \\
\hline Wales & & & $\begin{array}{l}-0.352 \\
(0.255)\end{array}$ & $\begin{array}{l}-0.427 \\
(0.279)\end{array}$ & & & & \\
\hline Scotland & & & $\begin{array}{l}-0.183 \\
(0.203)\end{array}$ & $\begin{array}{l}-0.074 \\
(0.199)\end{array}$ & & & & \\
\hline $\begin{array}{c}\text { Demographics: } \\
\text { Age }\end{array}$ & & & $\begin{array}{l}0.028 \\
(0.007)^{* *}\end{array}$ & $\begin{array}{l}0.019 \\
(0.006)^{* *}\end{array}$ & $\begin{array}{l}0.021 \\
(0.006) * *\end{array}$ & $\begin{array}{l}0.021 \\
(0.006)^{* *}\end{array}$ & $\begin{array}{l}0.018 \\
(0.006) * *\end{array}$ & $\begin{array}{l}0.020 \\
(0.006) * *\end{array}$ \\
\hline Female & & & $\begin{array}{l}-0.178 \\
(0.108)+\end{array}$ & $\begin{array}{l}-0.275 \\
(0.114)^{*}\end{array}$ & $\begin{array}{l}-0.274 \\
(0.116)^{*}\end{array}$ & $\begin{array}{l}-0.274 \\
(0.118)^{*}\end{array}$ & $\begin{array}{l}-0.279 \\
(0.112)^{*}\end{array}$ & $\begin{array}{l}-0.277 \\
(0.116)^{*}\end{array}$ \\
\hline
\end{tabular}




\begin{tabular}{|c|c|c|c|c|c|c|c|c|}
\hline & $(1)$ & $(2)$ & (3) & (4) & (5) & (5) & (7) & (8) \\
\hline Minority ethnic & & & $\begin{array}{l}0.017 \\
(0.160)\end{array}$ & $\begin{array}{l}-0.143 \\
(0.171)\end{array}$ & & & $\begin{array}{l}-0.113 \\
(0.171)\end{array}$ & \\
\hline $\begin{array}{l}\text { Marital status (base - single) } \\
\text { Married/Co-habiting }\end{array}$ & & & $\begin{array}{l}0.319 \\
(0.165)+\end{array}$ & $\begin{array}{l}0.329 \\
(0.173)+\end{array}$ & $\begin{array}{l}0.428 \\
(0.156)^{* *}\end{array}$ & $\begin{array}{l}0.434 \\
(0.158)^{* *}\end{array}$ & $\begin{array}{l}0.288 \\
(0.170)+\end{array}$ & $\begin{array}{l}0.343 \\
(0.164)^{*}\end{array}$ \\
\hline Separated/Divorced & & & $\begin{array}{l}0.158 \\
(0.235)\end{array}$ & $\begin{array}{l}-0.051 \\
(0.248)\end{array}$ & & & $\begin{array}{l}-0.002 \\
(0.251)\end{array}$ & \\
\hline Dependent children & & & $\begin{array}{l}0.077 \\
(0.105)\end{array}$ & $\begin{array}{l}-0.066 \\
(0.105)\end{array}$ & & & $\begin{array}{l}-0.120 \\
(0.106)\end{array}$ & \\
\hline $\begin{array}{l}\text { Highest educational level (base - no school } \\
\text { qualifications): } \\
\qquad \text { O-levels/GCSEs (aged 16) }\end{array}$ & & & $\begin{array}{l}-0.161 \\
(0.169)\end{array}$ & $\begin{array}{l}-0.066 \\
(0.105)\end{array}$ & & & $\begin{array}{l}-0.055 \\
(0.176)\end{array}$ & \\
\hline A-levels (aged 18) & & & $\begin{array}{l}0.046 \\
(0.177)\end{array}$ & $\begin{array}{l}0.060 \\
(0.180)\end{array}$ & & & $\begin{array}{l}0.066 \\
(0.184)\end{array}$ & \\
\hline Vocational higher qual. & & & $\begin{array}{l}0.102 \\
(0.222)\end{array}$ & $\begin{array}{l}0.237 \\
(0.225)\end{array}$ & & & $\begin{array}{l}0.343 \\
(0.225)\end{array}$ & \\
\hline College/university degree & & & $\begin{array}{l}0.183 \\
(0.181)\end{array}$ & $\begin{array}{l}0.334 \\
(0.185)+\end{array}$ & $\begin{array}{l}0.368 \\
(0.131)^{* *}\end{array}$ & $\begin{array}{l}0.383 \\
(0.132)^{* *}\end{array}$ & $\begin{array}{l}0.365 \\
(0.186)^{*}\end{array}$ & $\begin{array}{l}0.359 \\
(0.130)^{* *}\end{array}$ \\
\hline $\begin{array}{c}\text { Family and personal background: } \\
\text { Self-employed parent }\end{array}$ & & & $\begin{array}{l}-0.011 \\
(0.196)\end{array}$ & $\begin{array}{l}-0.008 \\
(0.194)\end{array}$ & & & $\begin{array}{l}-0.0004 \\
(0.200)\end{array}$ & \\
\hline $\begin{array}{l}\text { Self-employed parent who } \\
\text { employed }\end{array}$ & & & $\begin{array}{l}0.193 \\
(0.240)\end{array}$ & $\begin{array}{l}0.214 \\
(0.236)\end{array}$ & & & $\begin{array}{l}0.325 \\
(0.245)\end{array}$ & \\
\hline $\begin{array}{l}\text { Partner employed } \\
\text { (lagged) }\end{array}$ & & & $\begin{array}{l}-0.301 \\
(0.119) *\end{array}$ & $\begin{array}{l}-0.291 \\
(0.123)^{*}\end{array}$ & $\begin{array}{l}-0.384 \\
(0.129)^{* *}\end{array}$ & $\begin{array}{l}-0.393 \\
(0.130)^{* *}\end{array}$ & $\begin{array}{l}-0.310 \\
(0.123)^{*}\end{array}$ & $\begin{array}{l}-0.373 \\
(0.138) * *\end{array}$ \\
\hline $\begin{array}{l}\text { Partner self-employed } \\
\text { (lagged) }\end{array}$ & & & $\begin{array}{l}0.316 \\
(0.181)+\end{array}$ & $\begin{array}{l}0.116 \\
(0.186)\end{array}$ & & & $\begin{array}{l}0.450 \\
(0.191)^{*}\end{array}$ & $\begin{array}{l}0.432 \\
(0.204)^{*}\end{array}$ \\
\hline $\begin{array}{l}\text { Previous spells of self- } \\
\text { employment }\end{array}$ & & & $\begin{array}{l}0.720 \\
(0.159)^{* *}\end{array}$ & $\begin{array}{l}0.562 \\
(0.145)^{* *}\end{array}$ & $\begin{array}{l}0.669 \\
(0.153) * *\end{array}$ & $\begin{array}{l}0.677 \\
(0.155) * *\end{array}$ & $\begin{array}{l}1.367 \\
(0.183)^{* *}\end{array}$ & $\begin{array}{l}1.458 \\
(0.205)^{* * *}\end{array}$ \\
\hline Investment income (£000s, lagged) & & & $\begin{array}{l}0.020 \\
(0.016)\end{array}$ & $\begin{array}{l}0.021 \\
(0.018)\end{array}$ & & & $\begin{array}{l}0.029 \\
(0.022)\end{array}$ & \\
\hline County house price (moving std. dev.) & & & & & $\begin{array}{l}-0.096 \\
(0.051)+\end{array}$ & $\begin{array}{l}-0.106 \\
(0.050)^{*}\end{array}$ & $\begin{array}{l}-0.092 \\
(0.050)+\end{array}$ & $\begin{array}{l}-0.100 \\
(0.051)+\end{array}$ \\
\hline County unemployment rate (moving std. dev.) & & & & & $\begin{array}{l}-0.255 \\
(0.248)\end{array}$ & & $\begin{array}{l}-0.048 \\
(0.242)\end{array}$ & \\
\hline
\end{tabular}




\begin{tabular}{|c|c|c|c|c|c|c|c|c|}
\hline & (1) & $(2)$ & (3) & (4) & (5) & (6) & (7) & (8) \\
\hline Job satisfaction score - pay (lagged) & & & & & & & $\begin{array}{l}0.031 \\
(0.035)\end{array}$ & $\begin{array}{l}0.036 \\
(0.036)\end{array}$ \\
\hline Job satisfaction score - job security (lagged) & & & & & & & $\begin{array}{l}-0.058 \\
(0.033)+\end{array}$ & $\begin{array}{l}-0.061 \\
(0.034)+\end{array}$ \\
\hline Job satisfaction score - the work itself (lagged) & & & & & & & $\begin{array}{l}0.038 \\
(0.040)\end{array}$ & $\begin{array}{l}0.040 \\
(0.041)\end{array}$ \\
\hline Would like to work less hours (lagged) & & & & & & & $\begin{array}{l}-0.134 \\
(0.108)\end{array}$ & \\
\hline Would like to work more hours (lagged) & & & & & & & $\begin{array}{l}0.049 \\
(0.195) \\
\end{array}$ & \\
\hline $\begin{array}{l}\text { Rho } \\
\text { (p-value of LR test for significance) }\end{array}$ & & $\begin{array}{l}0.202 \\
(0.217) \\
\end{array}$ & $\begin{array}{l}0.444 \\
(0.002) * *\end{array}$ & $\begin{array}{l}0.308 \\
(0.083)+\end{array}$ & $\begin{array}{l}0.385 \\
(0.036)^{*}\end{array}$ & $\begin{array}{l}0.402 \\
(0.028)^{*}\end{array}$ & $\begin{array}{l}0.247 \\
(0.054)+\end{array}$ & $\begin{array}{l}0.323 \\
(0.040)^{*}\end{array}$ \\
\hline Log-Likelihood & -2006.6 & -2006.3 & -1925.7 & -1507.4 & -1511.2 & -1511.8 & -1349.8 & -1355.8 \\
\hline $\mathrm{N}$ & 7139 & 7139 & 7139 & 6293 & 6293 & 6293 & 5688 & 5688 \\
\hline Total number of spells & 2185 & 2185 & 2185 & 1950 & 1950 & 1950 & 1825 & 1825 \\
\hline Number of non-censored spells & 760 & 760 & 760 & 539 & 539 & 539 & 521 & 521 \\
\hline
\end{tabular}

Source: computed from BHPS Waves 8-15

Notes: Standard errors in brackets, ** denotes coefficient significance at $1 \%$ or less, * between 1 and $5 \%$, + between 5 and $10 \%$ 
Figure 1

\section{Baseline Hazard Functions}

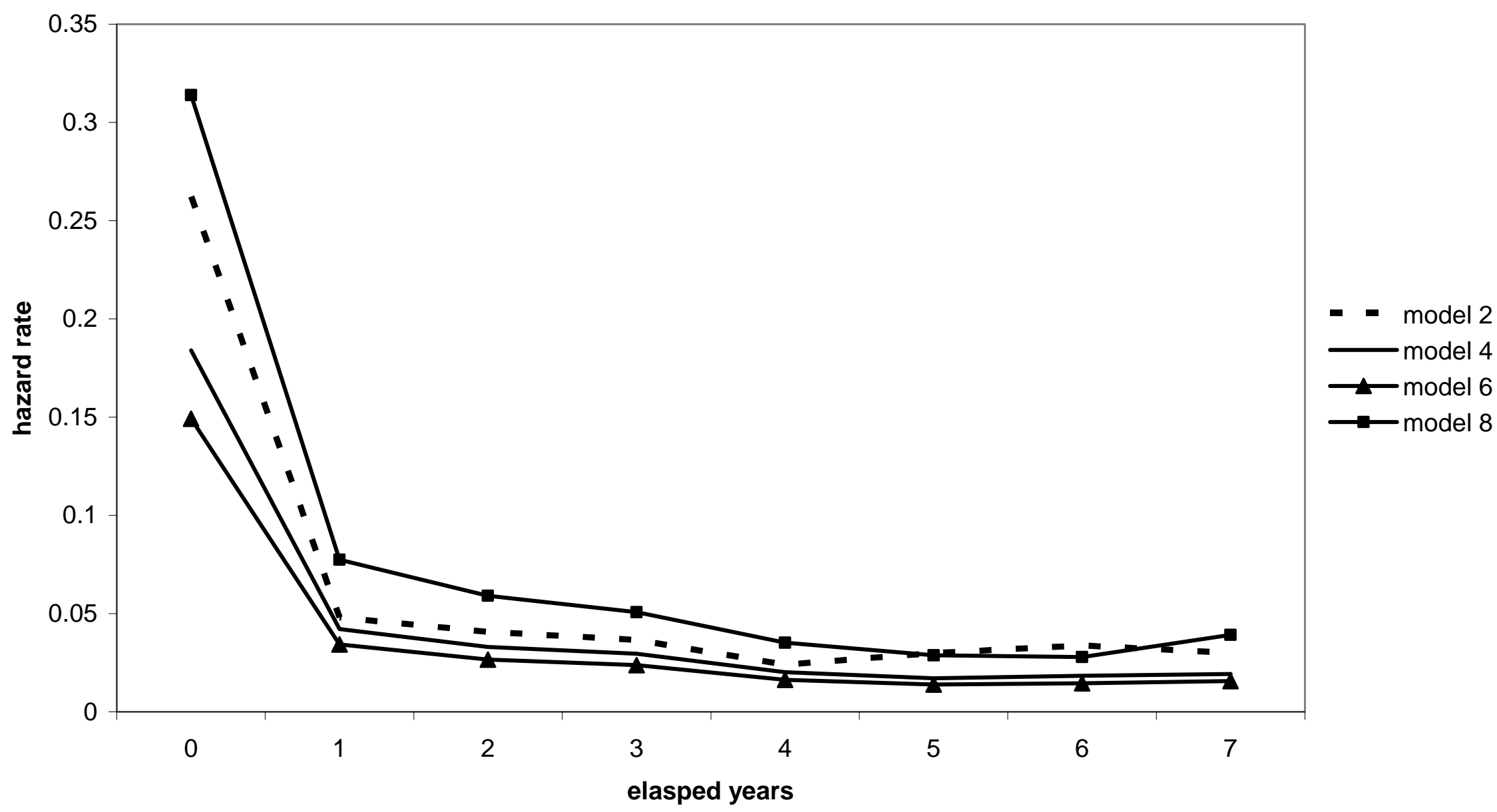

Note: baselines are constructed for a reference individual who is male, aged 40, married, with an employed spouse, living in the south of England in a locality with mean house price and unemployment volatility, with sample mean investment income. 